\title{
The Past as a Partitura: Peter Carey's Historical Novels
}

\begin{abstract}
In a literary text, repetition of previous motifs may constitute the poetics of a text, shape its themes and contribute to its interpretation. The following article will try to trace these aspects of repetition in four historical novels by Peter Carey which use it to both structure their texts and convey their specific political ideas. Referring to Oscar and Lucinda, Jack Maggs, True History of the Kelly Gang and Parrot and Olivier in America, it argues that Carey's fiction uses repetition as a strategy to both inscribe his works in literary and cultural traditions and to revisit and revise them in order to make room for other readings and interpretations.
\end{abstract}

Keywords: repetition, music, the past, post-colonialism, Peter Carey, historical novel.

\section{Repetition: the concept}

Repetition is ingrained in artistic practice as either literal imitation when a previous work of art is repeated in detail another time, or an allusion, or a more subtle interpretation, when a previous artefact is recalled in a different context. It may serve a variety of purposes: it may work as a vehicle for a nostalgic revisiting of older texts, or it may help to revise and question them, in a gesture of a critical return. In this sense, repetition may be seen as a process of cross-fertilisation, analogous to that of adaptation characterised by Brian McFarlane as a "desirable - even inevitable - process in a rich culture". ${ }^{1}$ Rich cultural production is inevitably marked by an incessant oscillation between extreme originality, always rare, and formulaic art based on equally extreme repetition leading to the exhaustion of the idea or aesthetics. This tension creates a fertile space for repetition seen, on the one hand, as a gesture of inscription into an artistic tradition and on the other, of creative transgression of this very tradition and producing new and original works.

\footnotetext{
1 B. McFarlane, Novel to Film, Oxford 1996, p. 10.
} 
Perhaps the best area to observe the workings of repetition as an artistic practice is music, where repetition functions at a number of levels. Most conspicuously, repetition may be the chief organising principle of some musical compositions - as is the case with the canon or with such pieces as Ravel's Bolero, where a theme is repeated with only minute changes of loudness or timing. Repetition may also shape the theme and the structure of another class of musical compositions, so-called variations in which the theme is borrowed from a previous composition and subsequently repeated in a series of transformations including different instrumentation, the addition of ornamentation, modulations and/or extensions. Variations evoke the familiar theme and then repeat it in a series of transformed sequences. Finally, the concept of repetition may be applied to the level of performance when the same theme is very differently interpreted despite the fact that the notation and instrumentation remain the same. Repetition, then, may organise the structure of a composition, its theme and performance which together create the final effect of a piece.

Treating music as a convenient - though never completely adequate - metaphor, one may analyse analogous processes operating in a literary text, where repetition may constitute the poetics of a text, shape its theme and contribute to its interpretation. The following article aims to trace these aspects of repetition in four historical novels by Peter Carey which use it to both structure their texts and convey their specific political ideas. Referring to Oscar and Lucinda (1988), Jack Maggs (1997), True History of the Kelly Gang (2000) and Parrot and Olivier in America (2010) I will argue that Peter Carey's fiction uses repetition to both inscribe his works in literary and cultural traditions and to actively revisit and revise them in order to make room for other readings and interpretations. Following the musical metaphor, Carey's novels may be read as examples of compositions which grow out of a past tradition and yet return to it without nostalgia, in a gesture of examination rather than eulogy.

\section{The poetics of repetition: narration and language}

\section{Repetition as doubling}

At the level of poetics, repetition in Carey's fiction is most visibly manifested in the textual doubling and/or mirroring of plots, narrators and narrative points of view. His historical novels are based on parallel plots organised by two characters whose fates and perspectives are alternated and intertwined within the larger structure of the text. This is most notably the case in Oscar and Lucinda, where the lives of the two main characters are presented in long alternating sequences shifting from England to Australia and back. The narrative makes it clear that the paths of such seemingly remote characters shall eventually cross: first due to the title, which signals their relationship, and then thanks to connecting passages interspersed within the text, e.g. "while Oscar Hopkins read Greats at Oriel, Lu- 
cinda Leplastrier nursed her mother". ${ }^{2}$ This connection demonstrates the narrative affinity of the two figures and their complementary, rather than separate fates, which are to meet in the future.

To some extent this narrative strategy is repeated in Jack Maggs, a rewriting of Dickens's Great Expectations, with the eponymous Jack Maggs playing the role of a textual reincarnation of Abel Magwitch. In contrast to the Dickensian text, Carey's novel makes room for the narrative voice and point of view of the character, making him not merely a protagonist in someone else's story or a plot mechanism but a narrator as well: parts of the novel, especially those describing his childhood and youth, are narrated by Maggs himself; the narrative includes also his letters to his "adopted" son, Henry Phipps. Thus, apart from the thirdperson omniscient narrator, the novel includes another voice and contrasts it with another point of view: that of one of the main characters. This strategy is repeated, although in different proportions, in True History of the Kelly Gang where most of the novel is narrated by the protagonist himself but the introductions to chapters inform the reader about the conditions of his testimony (e.g. that these are the transcripts of hand-written documents) and the frame narrative, also document-based, sets the scene of the last action of the eponymous gang. Thus, the personal, firstperson narration is framed by and embedded in a quasi-documentary omniscient narrative providing a broader context to the main character's testimony. Likewise, the text of Parrot and Olivier in America is divided into two narrative voices: that of the French aristocrat Olivier and his secretary-companion Parrot. Yet again, the narratives juxtapose two narrators and two very different viewpoints, extending the narrative perspective and complicating the account of the events.

In all of these cases the novels introduce parallel plots, alternating points of view, different versions of the story and differing perspectives on presented events, characters and problems. The texts are structured as multi-vocal, with the voices complementing and sometimes contradicting one another, thus clearly suggesting the relative and provisional character of any account: fictional (Oscar and Lucinda), belonging to the literary canon (Jack Maggs) or historical (True History and Parrot and Olivier). Carey's novels undermine and problematise any totalising visions of fictional characters and events, the experienced reality, or historical accounts. In contrast, they are all shown as complex and multi-aspectual, open to various interpretations rather than uncomplicated and finite. The repetition and doubling of structural elements of the texts (plots and narrative perspectives) leads to far-reaching consequences for the meaning of the novels and reveals their questioning stance.

\section{Repetition as imitation}

One more feature of the poetics of repetition exemplified in True History of the Kelly Gang is the repetition via imitation of the language of the protagonist. As Carey admits, the fictional narrative of the protagonist Ned Kelly was greatly inspired by his reading of the so-called Jerilderie letter: the document written by

\footnotetext{
2 P. Carey, Oscar and Lucinda, London 1988, p. 91-92.
} 
the historical Ned Kelly, in which he explained in his own words his motivations and presented the story of his life. ${ }^{3}$ The novel tries to imitate the language and style of the historical figure transcribed in the letter, with its speech patterns and vernacular expressions; the author assumes the role of a ventriloquist, imitating the voice of another speaker. Yet again, just as in the case of the fictional Jack Maggs, whose voice was introduced as a compensation for the silence he was subjected to in the Dickensian classic, this gesture offers the fictional Ned Kelly the voice and the language imitating those of the historical figure, thus making room for the hitherto rarely told story. It is the story of a bushranger, an outlaw and a folk hero, spoken in his - nearly - own words, asserting his autonomy and integrity, and demanding not merely justice, but primarily respect. Artistically, it is the main poetic device of the novel, informing its feeling of authenticity and authority, responsible for the creation of the illusion of the proximity of the character. Constructing the language of the novel as a repetition via imitation of the language of the historical figure, the novel expands the knowledge of the past and admits to it voices and points of view usually silenced as considered either undesirable or uninteresting.

Thus, the imitation of language may be treated as yet another aspect of repetition operating at the level of textual poetics: the repetition in a literary work of a documented or imaginary speech of a pre-existing character. It may work towards the empowering of the character and may be interpreted as a gesture of respect towards the hitherto marginalised figures: either because of their seeming unimportance (e.g. the colonial perspective marginalising Australian voices, as in Jack Maggs), or because of their criminal status and thus the position outside the society (as in both Jack Maggs and True History). Imitating their voices, the novels artistically validate such stories and points of view, including them into a literary and historical discourse and giving them the opportunity to "speak" alongside the more "respectable" ones. Artistic repetition is thus an emancipating strategy broadening the scope of available narratives. Following the musical metaphor, doubling may be compared to a sort of a canon, while imitation resembles the Romantic compositions interweaving folk melodies into their texture. Both extend the repertoire of existing forms and make repetition an instrument of innovation rather than merely a method of proliferation of old structures and ideas.

\section{Repetition as variation: themes}

In musical theory and practice variations involve the manipulation of the theme of the composition in order to transform it into a new work of music. Understood broadly, variation is a return to well-known and important themes to present them differently - by expanding, ornamenting, modulating and changing them, new aspects are added and new meanings and aesthetic features emerge.

3 R. McCrum, Reawakening Ned. Interview with Peter Carey, "The Observer” 2001, 7 January, p. 12. 
Variations involve structural elements of the work (e.g. its length, or complexity) but their aim is the expansion and complication of the theme.

Pursuing the metaphor, one may easily notice a comparable strategy operating in Peter Carey's historical novels. To various degrees, Oscar and Lucinda, Jack Maggs, True History of the Kelly Gang and Parrot and Olivier in America all try to vary well-known themes and expand the familiar portrayals of historical figures in order to complicate and refine seemingly obvious ideas. In Jack Maggs the well-known theme is literary: the novel takes up a canonical work of English literature and transforms it adding to it a new perspective (that of a returned convict) and a metafictional frame (the figure of a novelist, Tobias Oates who, much like a similar figure in J. M. Coetzee's Foe, manipulates and rewrites the convict's story to serve his novelistic purposes). Thus, the story is expanded and dislocated: instead of Dickensian Pip, it is the novelist and the convict that come to the fore. The variation changes the balance of the previous text and therefore also its theme: from a story of an initiation into social structures, the theme is transformed into a reflection on the marginalisation of colonial experience and the ethics of writing. Rewriting and expanding the canonical text of the English novel to include other than the colonial Britain's perspective, the novel does "poetic justice" to the voices and experiences silenced in the $19^{\text {th }}$-century literary discourse and in a postcolonial gesture "writes back" to the imperial literary centre (cf. Ashcroft, Griffiths and Tiffin). Expanding secondary characters and adding new ones, equipping them with their own voices and narratives as in musical variations the novel proposes a new theme which emerges and grows organically from the old, well-known one.

In a similar way, the well-known story of the Australian folk hero and a national legend, Ned Kelly, is varied and transformed by a series of dislocations and additions. The most important of them is granting the eponymous outlaw his own voice and status of the main narrator of the novel. In contrast to historical accounts of his figure, Ned Kelly moves from the object to the subject of his own story, which in turn changes from a mere account of events to the intimate portrayal of a man trapped by the vicissitudes of his times and by his low social position. Carey returns to the legend but switching the accents he reveals its more human perspective focusing on Kelly-the man and his (auto)biographical story. The novel expands the legend in several directions: it gives it an emancipating character, as the protagonist speaks himself and for himself; it authenticates his experience, as he speaks in his own voice; and it "humanises" the character, as the novel shows his childhood, family and various hardships he had to endure. Again, the variation in this case involves the change of balance between the elements of the previous text and privileging the so far silenced parties; it also involves the change of mood: from the impassionate historical or legal to personal and intimate. As a result, the theme itself is considerably transformed: from the story of a bushranger and a criminal, the novel changes into a meditation on social injustice and fate. 
Finally, the novel Parrot and Olivier in America, described as "an improvisation on the life of Alexis de Toqueville"4 similarly takes up both the historical figure of the French aristocrat and his study of American democracy and the wellknown account of his journey to America, George Wilson Pierson's Tocqueville and Beaumont in America. Thus, the novel is a variation on both the historical figure and the historical account of his seminal journeys, and adds yet another - this time, fictional - layer to this already complex account. In the novel, Carey keeps some facts meticulously close to the historical protagonist's biography and writing (his background, dates and observations), considerably changing others (his name, companion or love affair). As a result, the novel is a mixture of allusions to well-known facts and texts and a historical fantasy freely inventing its protagonists and events. It repeats the previous text, enriching it with manifestly fictional elements and emphasising its literariness by including letters, drawings and illustrations. Yet again, the variation employed in this novel changes the balance of its elements: the fictional story is focused less on the analysis of the relative merits and dangers of democracy, and more on the development of an unlikely friendship between the Don Quixote-Sancho Panza pair of characters. In this novel, then, repetition, though obvious and manifested (despite the changed names) is a repetition with a difference, and the shift towards the personal and private instead of the public and political marks an important departure from the historical sources and inspirations.

All three of the novels return to foundational stories of the Western, or more specifically the Anglophone culture: to the classical novel, the national legend or the important study, all of which are considered decisive for the formation of British and Australian identity, or the perception of America in the world. Each time, however, this return comes with a difference and considerably transforms the reading of the previous texts. Changing the importance of their elements, privileging other, more eccentric points of view, stressing different problems, giving voice to the protagonists or foregrounding more personal aspects together result in the creation of new texts whose indebtedness to the old ones is entirely clear, and yet whose novelty and originality is equally apparent. It may be observed, too, that in most of these cases this repetition is a variation by expansion: the novels add new angles and perspectives and enrich the familiar stories with aspects previously either silenced or unconsidered. Thus, repeating the well-known material with a difference, they broaden - if only imaginatively - the recorded experience of the past and bring to focus new themes and problems. In keeping with the musical analogy one may conclude perhaps that the themes traditionally contained in a suite become in Carey's fiction material for symphonies.

4 T. Mallon, Tocqueville: the Novel. Rev. of Parrot and Olivier in America by Peter Carey, "New York Times Sunday Book Review", 18 April 2010, p. 18. 


\section{Repetition as interpretation: politics}

In musical practice various interpretations of given compositions are an approved and desired phenomenon and comparisons of particular interpretations constitute almost a separate discipline of musical criticism. Interpretation may be described as an originality of approach and execution when faced with well-known themes; it consists in finding new ways to present familiar pieces while remaining faithful to their structure and theme. As such, it is an exhibition of technical mastery and the artistry of original approach.

All the above analysed texts by Peter Carey variously interpret well-known stories and works. Some of these interpretations are manifestly ideologically motivated: the rewriting of Dickens's Great Expectations in Jack Maggs is clearly done from the postcolonial perspective, especially in the light of the novel's ending presenting Australia rather than Britain as a land of freedom and dignity. Thus, the novel not only includes the perspective of colonised subjects; more importantly, it evidently tries to change the established hierarchy in which the imperial centre is valued positively while the colonial periphery may be at best noticed. In contrast, Carey's novel re-valorises the periphery, thus shaking the hierarchy and flattening, as it were, its highly arbitrary and power-based structure. As Bill Ashcroft, Gareth Griffiths and Helen Tiffin point out, postcolonial novelists "have rewritten particular works from the English 'canon' [...] not simply by reversing the hierarchical order, but by interrogating the philosophical assumptions on which that order was based". ${ }^{5}$ Carey's repetition and revisiting of the classical text, then, leads to the fundamental revision of the premises supporting the traditional political, aesthetic and literary hierarchies.

In the case of True History of the Kelly Gang repetition seems to be directed at the revising of the established historical versions of well-known events. Including other than the historians' perspectives and imaginatively referring to the testimonies of eye-witnesses and protagonists, the novel suggests the multi-vocal concept of the past which seems to be a cacophony of numerous voices rather than a disciplined composition. The rewriting of the story of Ned Kelly implies a different, much less organised notion of history which conceptualises it as an experience rather than study. Moreover, both Jack Maggs and True History draw attention to the inevitably constructed character of history writing. The figure of Tobias Oates the novelist who shamelessly exploits the "raw material" of Maggs's life to change it into an engaging story may be interpreted not only as a satirical portrayal of an unscrupulous novelist. More importantly, his abuses and manipulations may be a critical signal of shared and frequent processes that operate both in fiction and history writing: the processes of selection, ordering and structuring which ultimately shape the stories. Carey's novel in an exaggerated way dramatises the process of turning experience into fiction with all the manipulations and abuses they involve, and the very same processes become an implicit subject of True History of the Kelly Gang and Parrot and Olivier in America. In this context,

\footnotetext{
5 B. Ashcroft, G. Griffiths, H. Tiffin, The Empire Writes Back, London 2005 [1989], p. 32.
} 
the lack of the article preceding the title of the former novel is very significant: ultimately, it refrains from imposing the status of the authoritative account (suggested by the definite article), rejecting, however, also the status of a mere version of the past (which might be implied by the use of the indefinite article). Thus, the very title signals the tension between the authoritative and non-authoritative accounts of the past and draws attention to the more fundamental principles conditioning such hierarchies.

Finally, Oscar and Lucinda repeats and rewrites not only the familiar stories of the Australian colonial past but also the literary convention of the romance, which is revisited and revised in this novel. The text installs the familiar formula of the romance showing first the two protagonists living separately, then meeting and falling in love with each other, to be subsequently separated. The romance cycle, however, is never closed as in the plot twist marking the surprising ending of the novel the romance formula is shattered and radically modified, turning the novel into a melodrama rather than a traditional love story. In contrast to the familiar romance formula, activated by the title and the plot, the lovers are not reunited, love does not triumph and happiness is not the reward for patience. The novel plays both with the readers' expectations, and with the generic code of the novel, rewriting the familiar romance pattern with a change, thus showing its limitations and its perhaps already highly automatised character. By breaking the generic expectations connected with the romance, the novel refreshes the old form and introduces the element of novelty and originality.

Repetition, then, conceptualised as re-interpretation reveals a number of political and ideological attitudes. In Carey's fiction they range from the postcolonial valorisation of eccentric discourses, through the foregrounding of historiography's inescapable constructedness, to the revision of familiar literary conventions. It is a highly motivated gesture of rewriting, on the one hand in order to expand and complement the existing narratives, and on the other to question and problematise their foundational assumptions. It works to emancipate, displace and personalise canonical and foundational texts. Repetition with a difference, then, seems for Carey a tool of far-reaching revision and subversion aimed to probe, extend and possibly explode the traditional political, historical and literary discourses.

\section{Repetition repeated: conclusions}

As any rhetorical device, repetition has its politics and poetics; yet, it also has its motivations, forcing the contemporary novel in general and Peter Carey's fiction in particular to revisit and revise the political, historical and literary past, which looms behind the present and constitutes a perennial point of reference and return. The constant return to the past, in order to comprehend, complete or correct it, may be linked to the obsessive psychological need to return to the defining, and often traumatic moments in order to understand and hence "exorcise" them. Traditionally, psychoanalytic theory explains these returns in two very different ways, as driven by very different desires. In Freud's reading, the obsessive repetition is an attempt to regain control over the past and to reinstitute, albeit only 
in retrospect, the desired and disturbed bliss. As Ankhi Mukherjee suggests, in Freudian theory "repetition is a mode of recuperating loss, a ritual of control". ${ }^{6}$ In contrast, Lacanian theory sees repetition less optimistically, as a psychological attempt to regain something irretrievably lost, "a quest for lost pleasure through symbolic substitution" "and a symptom of alienation rather than mastery. Simplifying it crudely, as a psychological process, repetition may be conceptualised as either empowering or compensation.

It seems that in the case of literature and in Carey's fiction these two attitudes are intertwined. On the one hand, his "revisionary" novels return to the past with a purpose which may be defined as empowerment: they aim to recover lost voices and perspectives, bring them to the fore and thus to grant them - though only imaginatively - the subjectivity and mastery denied them in the past. It may be read, then, as an attempt to control the narrative of the past snatched by the so far dominating discourses. On the other hand, this return is undoubtedly marked by a considerable degree of fantasising and imaginative compensation: it tries to represent the past not as it really was, in the famous phrase of Leopold von Ranke, but as it might have - and perhaps should have - been; it creates an imaginary picture of something that has never existed in the first place. As Ankhi Mukherjee argues in her discussion of literary returns to Great Expectations, "[the] postmodern rewriting demonstrates [that] there is nowhere to return to, and nothing to remember, for what it 'repeats' compulsively is that which was never experienced". ${ }^{8}$ The two readings of repetition, Freudian and Lacanian, that see it either as an empowering practice or compensatory fantasising, do not, however, acknowledge one more feature connected with it, namely the pleasure connected with the recognition of familiar forms and themes and the variation they undergo. It may be the pleasure of not merely the return but also of creation of newness, of the inscription into the literary, historical or political tradition, and of their paradoxical, complicitous subversion. Repetition, thus, may be treated as a strategy of innovation deprived of the illusion of the possibility of absolute novelty and as a method to regain the past, if only imaginatively, and to retell it with a difference.

\section{Bibliography}

Ashcroft B., Griffiths G., Tiffin H., The Empire Writes Back, London 2005 [1989].

Carey P., Jack Maggs, London 2011 [1997].

Carey P., Oscar and Lucinda, London 1988.

Carey P., Parrot and Olivier in America, London 2010.

Carey P., True History of the Kelly Gang, New York 2002 [2000].

Oxford Dictionary of Musical Terms, ed. A. Latham, Oxford 2004.

${ }^{6}$ A. Mukherjee, Missed Encounters: Repetition, Rewriting, and Contemporary Returns to Charles Dickens's Great Expectations, "Contemporary Literature" 2005, vol. 46, no. 1, p. 109.

7 Ibid.

8 Ibid., p. 131. 
Mallon T., Tocqueville: The Novel. Review of Parrot and Olivier in America by Peter Carey, "New York Times Sunday Book Review" 2010, 18 April, p. 18.

McCrum R., Reawakening Ned. Interview with Peter Carey, "The Observer" 2001, 7 January, p. 12.

McFarlane B., Novel to Film, Oxford 1996.

Mukherjee A., Missed Encounters: Repetition, Rewriting, and Contemporary Returns to Charles Dickens's Great Expectations, "Contemporary Literature" 2005, vol. 46, no. 1, p. 108-133.

Pierson G. W., Tocqueville and Beaumont in America, Baltimore 1996 [1938].

Spice N., Forged, Forger, Forget. Review of Parrot and Olivier in America by Peter Carey, "London Review of Books" 2010, vol. 32, no. 15, 5 August, p. 14-16. 